\title{
KAJIAN AWAL SIMULASI KOMPUTER MODEL KEBIJAKAN PENENTUAN JUMLAH OPTIMAL ARMADA BUS RAPID TRANSIT (BRT) SEMARANG
}

\author{
Wiwik Budiawan \\ Program Studi Teknik Industri \\ Universitas Diponegoro \\ Email: wiwikbudiawan@ft.undip.ac.id \\ Ary Arvianto \\ Program Studi Teknik Industri \\ Universitas Diponegoro \\ Email: wiwikbudiawan@ft.undip.ac.id \\ Nabiel Putra Adam \\ Program Studi Teknik Industri \\ Universitas Diponegoro \\ Email: nabielputraa@gmail.com
}

\begin{abstract}
ABSTRAK
Keberadaan Bus Rapid Transit (BRT) di Kota Semarang diharapkan dapat menjadi salah satu solusi akan permasalahan kemacetan, adanya BRT ini terutama pada trayek perjalanan koridor II, ternyata mendapatkan tanggapan positif dari masyarakat pengguna, terbukti dari meningkatnya permintaan yang terjadi dari tahun 2012 hingga 2013 yakni hampir menyentuh angka 90\% dari tahun sebelumnya. Dari hasil pengamatan pada trayek perjalanan Koridor II yang telah dilakukan, ternyata diketahui bahwa pada beberapa shelter (halte) terjadi permintaan yang cukup tinggi, dan akhirnya pada saat peak hour armada BRT tidak mampu menampung seluruh permintaan yang terjadi, sehingga mengakibatkan penumpang harus menunggu lebih lama untuk dilayani oleh armada tersebut. Hal tersebut memicu permasalahan baru yakni kurang optimalnya jumlah armada yang beroperasi dan juga jadwal antar keberangkatan armada yang kurang menyesuaikan kondisi ketika tingginya permintaan pada setiap halte. Adapun metode yang digunakan adalah dengan melakukan pendekatan sistem, yang selanjutnya melakukan pemodelan sistem transportasi dan simulasi computer yang terjadi pada rute perjalanan tersebut. Hasil dari penelitian ini adalah rancangan model simulasi dalam bentuk model matematis dan simulasi komputer. Variabel pengendali pada model matematis dan simulasi komputer adalah frekuensi waktu antar kedatangan armada BRT, sehingga diharapkan mengurangi panjang antrian penumpang.
\end{abstract}

Kata kunci: sistem transportasi, pemodelan sistem, simulasi komputer.

\begin{abstract}
The existence of Bus Rapid Transit (BRT) in Semarang is expected to be one of the solutions would be the congestion problem, the BRT is mainly on the route of travel corridor II, it was getting positive feedback from the user community, as evidenced by the increased demand that occurred from 2012 to 2013 ie almost touching the figure of $90 \%$ from the previous year. From the observation on the route of travel corridor II has been done, it is known that in some shelter (stop) occurs demand is high enough, and finally during the peak hour fleet of BRT are not able to accommodate all the demand that occurred, resulting in the passengers have to wait longer to be served by the flotilla. This triggered a new problem that is less optimal number of buses operating between departure and also schedule a fleet of less adjusting the conditions when high demand at every stop. The method used is to perform a systems approach, which further modeling and computer simulation of transport system which occurred on the travel route. The results of this research is the design of the simulation model in the form of mathematical models and computer simulations. A control variable on mathematical models and computer simulations is the frequency of time between the arrival of a fleet of BRT, so it is expected to reduce the long queues of passengers.
\end{abstract}

Keywords: transportation systems, system modeling, computer simulation. 


\section{PENDAHULUAN}

Sebagai Ibu kota Provinsi Jawa Tengah, Kota Semarang berkembang sebagai pusat bisnis dan ekonomi di wilayah Jawa Tengah. Perkembangan Kota Semarang juga ditunjang oleh tingkat aksesibilitas yang cukup tinggi fasilitas transportasi, seperti: pelabuhan, bandara, stasiun, dan terminal. Fasilitas tersebut digunakan sebagai jalur utama mobilitas masyarakat yang menghubungkan kota - kota lain di sekitarnya (1). Hal ini berdampak pada kegiatan perekonomian di Kota Semarang yang terus meningkat. Hal ini dikarenakan letaknya yang strategis, yaitu berada di tengah pulau Jawa.

Meningkatnya mobilitas penduduk berimbas pada peningkatan kebutuhan akan sarana transportasi. Apabila antara kedua hal tersebut tidak terjadi keseimbangan, maka dapat menimbulkan kacaunya pola pergerakan yang terjadi di suatu kota serta berpotensi menimbulkan masalah - masalah lalu lintas di kota tersebut (2). Peningkatan mobilisasi warga Kota Semarang mendorong peningkatan kebutuhan akan sarana dan prasarana transportasi. Adapun moda transportasi yang digunakan masyarakat Kota Semarang dapat dikategorikan dalam dua kategori utama, yakni moda transportasi pribadi dan moda transportasi umum. Adapun moda transportasi umum yang beroperasi di Kota Semarang antara lain bus kota, angkutan kota (angkot), ojek dan taksi.

Pada dasarnya angkutan umum memiliki peran yang sangat signifikan, namun kondisi angkutan yang buruk akan menyebabkan turunnya efektifitas maupun efisiensi transportasi kota secara keseluruhan. Peran angkutan umum sangat penting dikarenakan sebagian masyarakat kota masih membutuhkannya untuk memenuhi kebutuhan mobilitasnya, dengan alasan tidak dapat menggunakan kendaraan pribadi, baik karena alasan fisik (terlalu kecil, sakit, atau terlalu tua), alasan legal (tidak mempunyai Surat Ijin Mengemudi), maupun alasan finansial (tidak memiliki kendaraan pribadi) (3).

Oleh karena itu, sangat beralasan jika dikatakan bahwa ketergantungan masyarakat perkotaan di Indonesia akan pelayanan angkutan umum relatif tinggi. Tetapi dengan semakin meningkatnya perekonomian masyarakat dan ditunjang dengan masih rendahnya tingkat pelayanan dari angkutan umum, menyebabkan pengguna angkutan umum semakin merosot dan beralih ke sepeda motor. Pada dasarnya, pengguna kendaraan angkutan umum menghendaki adanya tingkat pelayanan yang memadai, baik waktu tempuh, waktu tunggu maupun keamanan dan kenyamanan yang terjamin selama dalam perjalanan.

Sebagai upaya peningkatan kualitas pelayanan transportasi publik, rute ini telah dilayani moda transportasi terintegrasi yakni BRT (Bus Rapid Transit) koridor II sejak tahun 2012. Beroperasinya BRT koridor II pada rute Terboyo - Ungaran menambah jumlah angkutan umum yang beroperasi pada rute tersebut. Kepadatan lalu lintas pada rute ini disebabkan oleh pertumbuhan jalan yang tidak sebanding dengan pertumbuhan jumlah kendaraan yang melewati rute Terboyo - Ungaran. Menurut Bina Marga Kota Semarang pada tahun 2012, bahwa pertumbuhan panjang jalan dalam kurun waktu tiga tahun sejak 2009 hingga 2011 tidak sepadan dengan banyaknya pertumbuhan kendaraan bermotor di Kota Semarang, yakni sebesar $0,28 \%$ pada tahun 2010 dengan panjang jalan sebesar 2.786,28 kilometer dari tahun sebelumnya sebesar $2.778,29$ kilometer. Sedangkan pada tahun 2011 panjang jalan Kota Semarang cenderung stagnan.

Kondisi pengelolaan angkutan umum jalan raya khususnya bus di Kota Semarang juga mengalami penurunan jumlah penumpang dikarenakan masyarakat lebih memilih menggunakan kendaraan pribadi, lebih - lebih armada bus banyak yang tidak layak jalan tetap beroperasi, lamanya perjalanan jika menggunakan angkutan, serta tarif yang kurang terjangkau menyebabkan masyarakat lebih memilih menggunakan kendaraan pribadi (4). Sedangkan kondisi angkutan kota (angkot) di Kota Semarang 90 persen sudah tidak layak pakai, sehinga masyarakat calon penumpang juga semakin menjauh, dan dikhawatirkan akan segera punah (5).

Pengadaan Bus Rapid Transit (BRT) merupakan salah satu jawaban akan kehausan masyarakat terhadap kebutuhan angkutan massal yang nyaman. Sekaligus upaya dalam mengurangi kemacetan dan usaha memperbaiki kualitas lingkungan (6). Adanya BRT di Kota Semarang ini, terutama pada trayek perjalanan Koridor II ternyata mendapatkan feedback positif dari pengguna angkutan umum, hal ini dibuktikan dari jumlah penumpang BRT Koridor II yang mengalami peningkatan dari tahun 2012 hingga tahun 2013 yakni pada tahun 2012 jumlah permintaan yang terjadi adalah sebesar 136.848 penumpang sedangkan pada tahun 2013 meningkat menjadi 248.134 penumpang (7). Konsep BRT merupakan sistem angkutan massal yang terintegrasi di setiap koridor, yang bertujuan untuk memenuhi kebutuhan masyarakat akan transportasi dalam kota. Namun sayangnya kebijakan penerapan BRT tersebut ternyata belum dapat terselenggara dengan baik di berbagai kota (8).

Sedangkan, berdasarkan hasil penelitian yang telah dilakukan diketahui bahwa bagi mayoritas masyarakat pengguna BRT di Kota Semarang, kendaraan pribadi roda dua merupakan barang subtitusi dari penggunaan armada BRT Trans Semarang. Sehingga mereka cenderung meminta jumlah armada yang lebih banyak daripada pengguna BRT yang tidak memiliki kendaraan pribadi (1). 
Adapun hasil observasi awal yang telah dilakukan, diketahui ada beberapa halte terdapat penumpang yang menunggu lebih lama dikarenakan armada bus sudah penuh, sehingga penumpang harus menunggu armada selanjutnya. Hal ini menjadi indikasi bahwa mulai terjadi ketidakseimbangan antara permintaan dengan armada BRT yang beroperasi. Guna mendapatkan keseimbangan antara jumlah penumpang terhadap armada BRT yang beroperasi, dapat ditempuh dengan cara meminimumkan durasi waktu penumpang menunggu BRT terhadap jumlah armada BRT yang sebaiknya disediakan dan juga waktu operasional dari setiap armada BRT. Tujuan dari penelitian ini adalah untuk mencoba memberikan tools guna mengevaluasi keseimbangan tersebut agar tercapai pelayanan yang lebih efektif.

Kejadian stokastik merupakan kejadian dimana nilai atau besaran dari suatu kejadian tersebut hanya dapat ditentukan distribusi frekuensinya, sehingga kejadian stokastik tidak dapat ditentukan fungsinya dengan pasti, melainkan hanya kisaran fungsi yang nilainya belum dapat ditetapkan (9). Dalam penelitian ini, komponen yang memiliki perilaku stokastik adalah fungsi dari kedatangan penumpang BRT dan juga kecepatan tempuh dari BRT, sehingga kedua komponen tersebut secara acak mengikuti salah satu bentuk dari distribusi statistik.

Studi mengenai pola perjalanan masyarakat memiliki banyak faktor dan juga sifat dari kondisi yang dinamis dan tidak mudah untuk dijabarkan kedalam permodelan matematis secara sederhana. Pendekatan yang dapat dilakukan salah satunya adalah dengan permodelan sistem dinamis (10). Sedangkan pendekatan model simulasi dapat digunakan untuk mengkaji permasalahan dalam sebuah sistem yang dinamis, seperti pada permasalahan sistem transportasi yang memiliki tingkat sosial cukup tinggi (11), dengan melakukan pendekatan model simulasi nantinya diharapkan dapat memperoleh hasil yang optimal (12).

Berdasarkan pemaparan diatas, dengan menggunakan pendekatan simulasi dari model sistem transportasi yang telah dirancang, diharapkan dapat memberikan solusi yang optimal dari jumlah armada bus BRT agar dapat memenuhi permintaan yang ada pada trayek perjalanan Sisemut - Terboyo.

\section{METODE}

Sistem merupakan sekumpulan objek yang memiliki ketergantungan dan saling berinteraksi untuk mencapai tujuan yang logis dalam suatu lingkungan yang kompleks. Objek yang menjadi komponen dalam sistem dapat berupa objek terkecil dan dapat berupa sub - sistem atau sistem yang lebih kecil. Sedangkan definisi sistem menurut para ahli adalah:

a. Sistem merupakan sekelompok dua atau lebih komponen - komponen yang saling berkaitan (interrelated) atau sub elemen - sub elemen yang bersatu untuk mencapai tujuan yang sama (common purpose) (13)

b. Sistem adalah sekelompok elemen yang terintegrasi dengan maksud yang sama untuk mencapai suatu tujuan (14)

c. Sistem merupakan suatu himpunan komponen atau variabel yang terorganisasi, saling berinteraksi, saling bergantung satu sama lain dan terpadu (15)

Sedangkan sistem memiliki karakteristik dimana antar objek di dalam sistem maupun dengan objek di luar sistem terdapat hubungan yang bersifat umpan balik yang menyebabkan sistem senantiasa bersifat dinamis. Sedangkan lingkungan sistem adalah segala sesuatu yang tidak merupakan bagian dari sistem, tetapi keberadaannya dapat mempengaruhi dan atau dipengaruhi sistem. Sistem disebut terbuka jika ada objek di luar sistem yang mempengaruhi objek di dalam sistem, dalam hal sebaliknya, sistem disebut tertutup. Karakteristik lain adalah sistem bersifat continuous atau discrete tergantung kepada apakah variabel yang diamati mempunyai nilai pada setiap titik waktu atau hanya pada setiap periode waktu tertentu, atau bersifat deterministik atau stokastik jika tidak ada atau setidaknya satu variabel yang probabilistik. Proses karakterisasi sistem ini juga diharapkan memberikan gambaran model konseptual sistem tersebut, faktor input yang berpengaruh pada sistem (decision variable) dan output variable yang akan diukur untuk mengevaluasi kinerja sistem tersebut.

Melakukan pengamatan pada sebuah sistem tidak hanya dapat mendefinisikan komponen komponen pendukung sistem, namun harus dapat mengetahui perilaku dan variabel - variabel yang ada di dalamnya setidaknya melakukan analisis terhadap sistem yang harus dapat memuat konsepsi mengenai sistem yang sedang diamati. Terdapat beberapa cara untuk dapat merancang, menganalisa dan mengoperasikan suatu sistem, salah satunya adalah dengan menggunakan permodelan, yakni membuat model dari sistem yang sedang diamati. Pemodelan (modelling) dapat diartikan sebagai suatu perwakilan atau abstraksi dari sebuah obyek atau situasi aktual (16). Istilah lainnya disebut tiruan model dunia nyata yang dibuat virtual (17). Adapun dua sasaran pokok dari modeling yakni: 
a. Untuk memperoleh pengertian yang lebih baik mengenai hubungan sebab - akibat (cause - effect) dalam suatu sistem, serta untuk menyediakan interpretasi kualitatif dan kuantitatif yang lebih baik akan sistem tersebut.

b. Modeling lebih terapan atau berorientasi pada masalah yaitu untuk mendapatkan prediksi yang lebih baik akan tingkah - laku dari sistem yang digunakan segera dalam perbaikan pengendalian atau pengelolaan sistem (18).

Kompleksnya permasalahan transportasi yang terjadi maka perlu adanya permodelan transportasi guna menyederhanakan permasalahan dan memudahkan dalam pengambilan keputusan. Model dapat didefinisikan sebagai bentuk penyederhanaan suatu relita atau dunia yang sebenarnya, termasuk di antaranya adalah :

a. Model fisik, seperti model arsitek, model teknik sipil, wayang golek, dan lainnya

b. Peta dan diagram grafis

c. Model statistika dan matematika (persamaan) yang menerangkan beberapa aspek fisik, sosial ekonomi dan model transportasi.

Permodelan transportasi sangat bermanfaat bagi perencanaan transportasi, karena melalui permodelan tersebut proses perencanaan dan pengambilan keputusan dari berbagai masalah transportasi dapat disederhanakan (19). Terdapat beberapa faktor yang perlu diperhatikan dalam menentukan permodelan analisis transportasi, yaitu :

a. Struktur Model

Yaitu suatu model dapat saja memiliki struktur yang sederhana yang berupa fungsi dari beberapa alternatif yang saling tidak berhubungan, atau struktur yang kompleks sehingga perlunya dihitung peluang dari suatu kejadian transportasi yang pernah terjadi. Dengan berkembangnya model kontemporer maka dapat dimungkinkan untuk menyusun model yang sangat umum dengan banyak peubah atau variabel.

b. Bentuk Fungsional

Yaitu bentuk model yang dapat memecahkan masalah dalam bentuk linear atau non - linear. Pemecahan masalah yang tidak linear mencerminkan realita masalah yang lebih tepat namun membutuhkan banyak sumber daya dan teknik untuk proses kalibrasi bagi model tersebut.

c. Spesifikasi Variabel

Yaitu menetapkan spesifikasi variabel yang dapat digunakan dan bagaimana variabel tersebut berhubungan satu sama lain dalam suatu model. Sehingga untuk menjelaskannya perlu proses tertentu dalam menentukan variabel yang dominan, antara lain melalui proses kalibrasi dan keabsahan (19).

Selanjutnya, di dalam model perencanaan transportasi merupakan gabungan dari beberapa seri sub model yang masing - masing harus dilakukan secara terpisah dan berurutan. Sub model tersebut adalah :

a. Aksesibilitas

b. Bangkitan dan tarikan pergerakan

c. Sebaran pergerakan

d. Pemilihan moda

e. Pemilihan rute

f. Arus lalu lintas yang dinamis

Seperti yang diungkapkan oleh Tamin (20), prosedur statistik biasa digunakan dalam permodelan transportasi. Di dalam permodelan ini, mensyaratkan data yang benar guna menaksir parameter model, sehingga di dalam penaksiran tersebut, sering timbul masalah galat atau kesalahan dalam perhitungan secara statistik. Pendekatan statistik akan memudahkan dalam perencanaan transportasi, walaupun dengan adanya galat tersebut sulit untuk mendekati realita, namun telah dapat mendekati gambaran sebenarnya. Hal ini dikarenakan data yang didapat tidak pernah jauh dari galat pada setiap tahapan pengumpulan data. Namun demikian, permodelan transportasi dengan menggunakan pendekatan statistik memiliki tujuan akhir sebagai model peramalan.

Berdasarkan hasil pengamatan di lapangan, selanjutnya peneliti menentukan variabel - variabel yang dipergunakan dalam melakukan penelitian, adapun identifikasi variabel ini dipergunakan untuk membatasi cakupan variabel yang dipergunakan dalam perancangan model dari sistem yang diamati seperti yang ditunjukkan pada tabel 1 . 
Tabel 1. Identifikasi Variabel

\begin{tabular}{cc}
\hline Terkendali & Tidak Terkendali (Eksternal) \\
\hline Waktu Tempuh BRT & Kedatangan Penumpang \\
Penumpang Menunggu & Rasio Penumpang Turun \\
Penumpang Naik & Jumlah Bus Beroperasi \\
Waktu Datang BRT & Jarak Antar Halte \\
Penumpang Turun & Kecepatan BRT \\
Jumlah Penumpang & Waktu Bus Mulai \\
Sisa Okupansi & \\
Load Factor & \\
Waktu Tinggal & \\
Probabilitas Penumpang Dilayani & \\
\hline
\end{tabular}

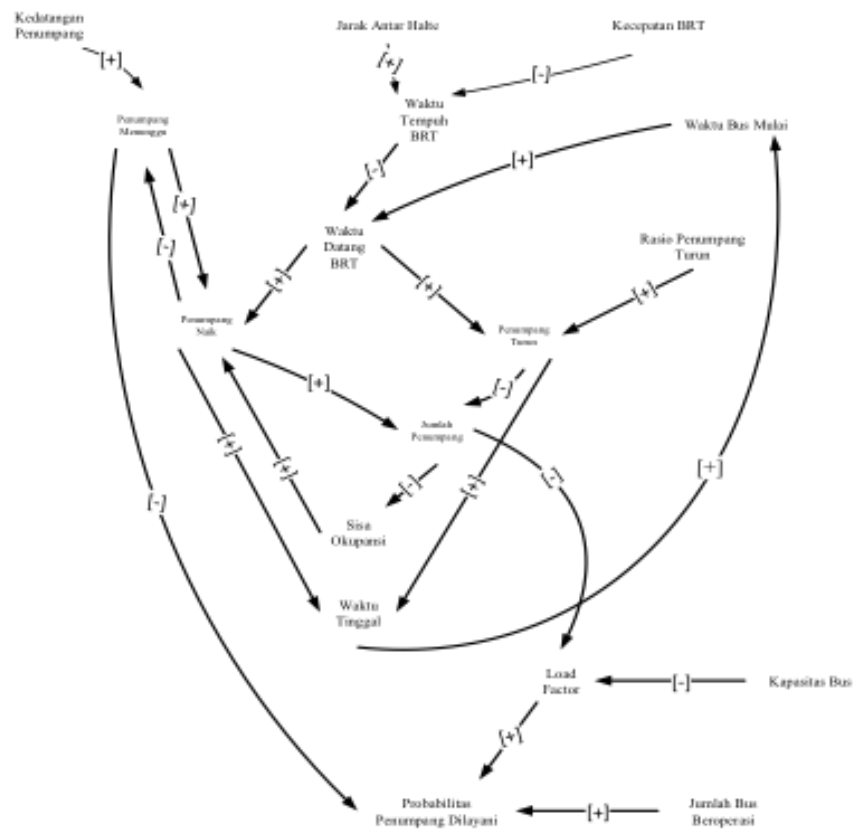

Gambar 1. Hubungan Kausalitas Model Layanan Penumpang

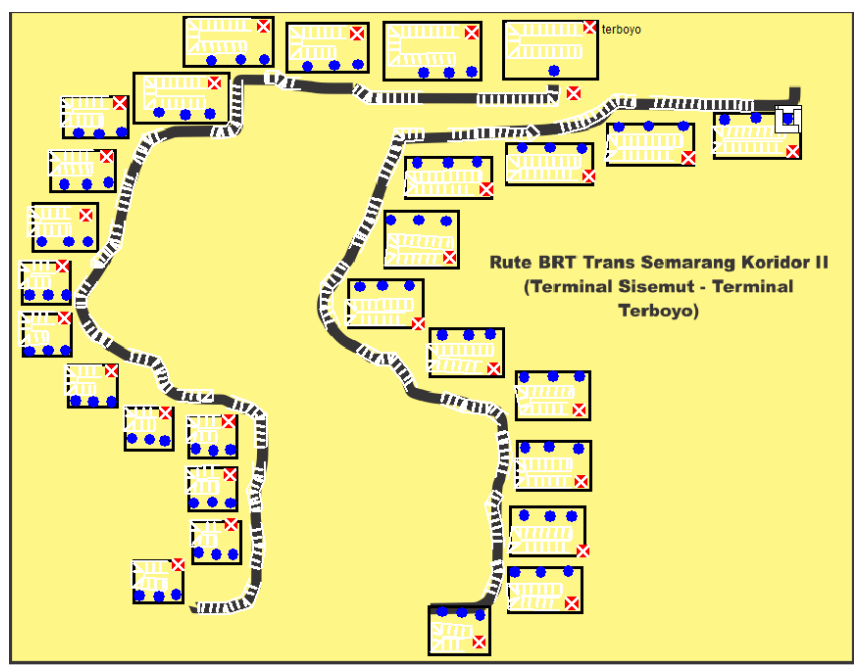

Gambar 2. Rancangan Simulasi

\section{HASIL DAN PEMBAHASAN}

Berdasarkan hasil rancangan model simulasi terdapat aspek penting yang perlu dipersiapkan dalam memulai simulasi komputer, antara lain yaitu dari data hasil bangkitan : 
a. Data kedatangan penumpang setiap halte

Data tersebut selanjutnya akan dianalisa guna mendapatkan keseuaian dengan salah satu distribusi statistik yang ada. Pengolahan data tersebut dilakukan dengan menggunakan bantuan perangkat lunak EasyFit Distribution Fitting. Selanjutnya hasil dari analisa yang telah dilakukan, akan menjadi masukan pada variabel simulasi yang telah dirancang

b. Data asal dan tujuan penumpang untuk setiap halte

Data tersebut merupakan hasil dari kuesioner yang telah disebarkan, nantinya dilakukan pemetaan terhadap asal dan tujuan masyarakat guna beraktifitas. Sehingga diperoleh seberapa besar rasio penumpang naik pada halte ke $-\mathrm{n}$ dan akan turun pada halte $\mathrm{ke}-\mathrm{n}+1$

Sedangkan data operasional BRT yang perlu dilakukan analisa adalah informasi mengenai kecepatan BRT, data ini nantinya diolah dengan bantuan perangkat lunak EasyFit Distribution Fitting untuk mendapatkan kesesuaian karakteristik terhadap salah satu distribusi statistik yang ada.

\section{KESIMPULAN}

Hasil perancangan simulasi komputer menunjukan ada dua kelompok variabel yang berperan dalam membantu menentukan kebijakan penentuan jumlah armada BRT. Salah satu kelompok variabel yang dapat rekayasa oleh pengambil kebijakan (decision maker) adalah variabel terkendali (control variable). Variabel terkendali tersebut antara lain: waktu tempuh BRT, Penumpang naik, turun dan menunggu, waktu kedatangan BRT, jumlah penumpang, sisa okupansi, load factor, waktu tinggal dan probabilitas penumpang dilayani.

\section{DAFTAR PUSTAKA}

[1] Putra, T. A., \& Kurnia, A. S. Diponegoro Journal of Economics. Analisis Preferensi Masyarakat Terhadap Bus Rapid Transit (BRT) Trans Semarang , III (1), 1-15. Semarang: 2014.

[2] Wibowo, P. A. Wahana Teknik Sipil. Kajian Jaringan Jalan Kota Semarang , XIII (13), 169-176. Semarang: 2008.

[3] Sholichin, I., \& Herijanto, W. Article of Civil Engineering. Evaluasi Penyediaan Angkutan Penumpang Umum dengan Menggunakan Metode Berdasarkan Segmen Terpadat, Rata - Rata Faktor Muat dan Break Even Point (Studi Kasus: Trayek Terminal Taman - Terminal Sukodono), 31-38. Semarang: 2008.

[4] Agatha, Nurcahyanto, \& Musawa. Strategi Pengelolaan Angkutan Umum Jalan Raya di Kota Semarang . Semarang: 2011.

[5] Isti, B.. Angkot di Semarang Menunggu Punah. Dipetik Agustus 24, 2014, dari SuaraMerdeka.com: http://www.suaramerdeka.com/v1/index.php/read/news_smg/2014/07/02/207954/Angkot-diSemarang-Menunggu-Punah

[6] Kusumaningtyas, S. BRT, Transportasi Massal yang Didamba. Dipetik Agustus 24, 2014, dari Liputan6.com: http://citizen6.liputan6.com/read/478623/brt-transportasi-massal-yang-didamba

[7] Trans Semarang. Data Jumlah Penumpang Koridor II. Semarang: Kantor Badan Layanan Umum Kota Semarang. Semarang: 2012

[8] Siahaan, D. A., Subowo, A., \& Marom, A. Implementasi Kebijakan Bus Rapid Transit (BRT) Trans Semarang di Kota Semarang. Semarang: 2013

[9] Widowati, \& Sutimin. (2007). Buku Ajar Pemodelan Matematika. Semarang: FMIPA UNDIP.

[10] Chao, Y., \& Zishan, M. (2013). 13th COTA International Conference of Transportation Professionals (CICTP 2013). System Dynamics Model of Shanghai Passenger Transportation, 1110-1118.

[11] Osorio, C., \& Bierlaire, M. (2010). A simulation-based optimization framework for urban traffic control.

[12] Barton, R. R., \& Meckesheimer, M. (2006). Metamodel-Based Simulation Optimization. In S. G. Henderson, \& B. L. Nelson, Handbook in OR \& MS (pp. 535-574). Elsevier B.V.

[13] Tamin, O. Z. (1997). Perencanaan dan Permodelan Transportasi. Bandung: ITB Press.

[14] Hall, J. A. (2001). Sistem Informasi Akuntansi (3rd ed.). Jakarta: Salemba Empat.

[15] McLeod, R. J. (2001). Sistem Informasi (7th ed., Vol. II). Jakarta: Prenhallindo.

[16] Lucas, H. C. (1993). Analisis, Desain, dan Implementasi Sistem Informasi. Jakarta: Erlangga.

[17] Eriyatno. (1998). Ilmu Sistem : Meningkatkan Mutu dan Efektivitas Manajemen. Bogor: IPB Press.

[18] Sterman, J. D. (2000). Business Dynamics: System Thinking and Modeling for a Complex World. McGraw Hill.

[19] Jones, K. (1995). Simulations : A Handbook for Teachers and Trainers. New Jersey. 